\title{
REWRITING THE NATION: GERMAN-TURKISH TRANSFORMATIONS OF THE BILDUNGSROMAN
}

\section{Lea Laura Heim}

European University Viadrina. Frankfurt (Oder), Germany. Email: euv153 494[at] europa-uni.de

\begin{abstract}
Literatures arising in the context of migration and cultural contact are known to provoke the nationally confined canonisation of literature. While the view that socalled 'migrant literature' does belong to German literature and culture is widely established within recent scholarship, the literary means of claiming space in the national canon are still an under-researched topic. The purpose of the study is to analyse the literary means of claiming space in the national canon and thereby investigate the permeability of its boundaries. By rewriting a canonical genre of German literature, which is historically linked to the emergence of a sense of a national identity, the analysed German-Turkish texts are using the Bildungsroman as a frame of reference to articulate pluralistic national identities. They further inscribe historical representations that have been omitted from dominant historical discourse into the national cultural memory. While rewriting the genre, the texts participate in the actualisation of the Bildungsroman and thereby reposition its traditional boundaries. Finally, the novels express the need to renegotiate the concept of the nation as well as its demand for homogeneity.
\end{abstract}

Keywords

bildungsroman; border studies; genre studies; german-turkish literature; historiographic metafiction; migration literature; mimicry; nation; national canon; rewriting

This work is licensed under a Creative Commons «Attribution» 4.0 International License 


\title{
ПЕРЕПИСЫВАЯ НАЦИЮ: НЕМЕЦКО- ТУРЕЦКИЕ ТРАНСФОРМАЦИИ В ПСИХОЛОГИЧЕСКОМ РОМАНЕ
}

\author{
Хейм Леа Лаура \\ Европейский университет Виадрина. Франкфурт-на-Одере, Германия. \\ Email: euv153 494[at]europa-uni.de
}

\begin{abstract}
Аннотация
Литературные произведения, возникающие в контексте миграции и культурных контактов, как известно, провоцируют национально ограниченную канонизацию литературы. В то время как мнение, что так называемая «литература мигрантов» действительно принадлежит к немецкой литературе и культуре, широко утвердилось в недавних исследованиях, литературные средства, используемые для того, чтобы претендовать на место в национальном каноне, все еще остаются малоисследованной темой. Наша цель проанализировать литературные средства утверждения места в национальном стандарте и тем самым исследовать проницаемость его границ. Переписывая канонический жанр немецкой литературы, который исторически связан с возникновением чувства национальной идентичности, проанализированные немецко-турецкие тексты используют Bildungsroman (роман воспитания) как основу для выражения плюралистических национальных идентичностей. Они также вписывают исторические представления, которые были исключены из доминирующего исторического дискурса, в национальную культурную память. Перелагая жанр романа воспитания, тексты участвуют в его актуализации и тем самым меняют его традиционные границы. Наконец, романы выражают необходимость пересмотреть концепцию нации, а также ее требование однородности.
\end{abstract}

\section{Ключевые слова}

роман воспитания; пограничные исследования; жанровые исследования; немецко-турецкая литература; историографическая мета-художественная литература; миграционная литература; мимикрия; нация; национальный канон (стандарт); переписывание (переложение)

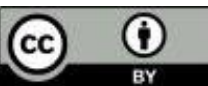

Это произведение доступно по дицензии Creative Commons «Attribution» («Атрибуция») 4.0 Всемирная 
Журнал Фронтирных Исследований. 2021. No 2 | ISSN: 2500-0225

Пограничные исследования в современной европейской литературе | Doi: https://doi.org/10.46539/jfs.v6i2.291

\section{INTRODUCTION}

The feeling or awareness of belonging to a group is a crucial factor in establishing an identity. A sense of identity develops through the distinction towards other groups. Therefore, in addition to belonging, exclusion must be considered as well when analysing the formation of identities. When imagining and constructing national identities, processes of demarcation also take place through socially and culturally constructed boundaries towards marginalised groups within a society. This is also reflected in the constitution of a national canon, from which literatures of migration have traditionally been excluded. To investigate how permeable the boundaries of a nationally confined canon are, literary means that confront and oppose this marginalisation are at the centre of this article.

Many Turks came to the Federal Republic of Germany in line with the bilateral agreements arranging the recruitment of foreign workers to meet the shortage of labour force after World War Two. Contributing significantly to the so-called 'Wirtschaftswunder', the migrant workers were joined by political refugees in the 1980s and 1990s fleeing the Turkish military and right-wing regimes. Today, Germany has the largest Turkish diaspora, including a rich tradition of German-Turkish literature that the analysed texts are part of.

Aysel Özakin's Die blaue Maske (1989) (The Blue Mask) and Emine Sevgi Özdamar's Die Brücke vom Goldenen Horn (1998) (The Bridge of the Golden Horn) will be discussed as transformations of the Bildungsroman. Both texts employ female protagonists who migrate from Turkey to Germany and are active in the New Left.

Apart from a shared culture of remembrance, it is especially the stories and, therefore, also literary narratives which contribute to the imagination of a national community (Brennan, 1990, p. 49). ${ }^{1}$ The Bildungsroman is of particular importance to the German context, as the emergence of the genre at the end of the $18^{\text {th }}$ century, as well as the associated idea of a Kulturnation, are closely linked to the development of a German national identity (Gutjahr, 2007, p. 18).

Based on the methodical premise of understanding genres as active classification systems with modifying boundaries, this study aims to examine the literary means by which the discussed novels inscribe themselves into the canonical genre of the Bildungsroman and thereby shift and blur its traditional boundaries. Furthermore, it will be discussed how the texts demand

1 The fact that national communities are imagined was prominently depicted by Benedict Anderson (2006). 
discursive participation on an artistic and aesthetic level and thereby claim space in the national literature and cultural canon.

\section{COSMOPOLITANISATION OF GERMAN LITERATURE AND CULTURE THROUGH GERMAN-TURKISH TEXTS}

'Guestworker literature' and 'literature of the affected', minority literature, multi-, inter-, or transcultural literature, the attempts to adequately label the texts written by authors with migration background or experience in relation to German literature are numerous. Above all they refer to their exclusion from a canon, which is determined by national boundaries. The increasingly established term of 'migration literature' continues to attribute a special status to the respective texts within the national literature, which a majority of authors perceive as inappropriate and as a means of stigmatisation (Grjasnowa, 2019, p. 135).

Following the expanded possibilities of publication created by a number of newly founded left-wing publishing houses in the 1960s and 1970s (Sievers, 2008), research on 'migration literature' started to develop in the 1980s and 1990s in the Federal Republic of Germany and more so in the USA. ${ }^{1}$ The texts were initially perceived to be socio-historical documents, and it was only in the 1990s that their aesthetic potential started to be of interest. Subsequently, the positive effects of migration and multilingualism were increasingly highlighted when dealing with such texts. Since the beginning of the new millennium, research that emphasises the belonging of 'migration literature' to the German national literature has increased (Esselborn, 2009). ${ }^{2}$ Commercial and competitive success with literary awards is a further indicator that '[i]mmigrant and ethnic-minority authors and their texts have arrived at the centre of the German literary field' (Sievers \& Vlasta, 2018, p. 248).

An initial male dominance in the area of German-Turkish literature has been evened out since the 1980s, and we are now looking at a body of texts that is plentiful in number and variety of thematic and stylistic orientations. Accordingly, Leslie A. Adelson (2005) has proclaimed a Turkish Turn in Contemporary German Literature, which has been developing since the 1970s and manifested more broadly in the 1990s. ${ }^{3}$ Rather than locating migrants

1 It shouhld be noted here that 'migration literature' as such did not exist in the German Democratic Republic. This relates to the comparatively lower migration rate and to the fact that corresponding texts were not perceived to be 'migration literature.' It should also be added that despite a longer history of migration to Germany, 'migration literature' was only recognised as a phenomenon after the post-war work immigrations had taken place (Sievers \& Vlasta 222f.).

2 For an extensive overview of respective research see Sievers \& Vlasta (2018).

3 In reference to Adelson, Brigid Haines (2008) proclaims an Eastern Turn in German literature, following the increasing number of publications by authros from Eastern Europe and former Yugoslavia in German. She as well argues that 'this literature cannot be considered "other", or 
between two worlds, Aldesons develops the concept of touching tales, describing "literary narratives that commingle cultural developments and historical references generally not thought to belong together in any proper sense' (Adelson, 2005, p. 20).1 She perceives literatures of Turkish migration to be an integral part of German literature and stresses their role in shaping and transforming the German cultural memory through their 'labor of imagination' while at the same time describing a shared future for Turkish and German culture (Adelson, 2005, pp. 12-14).

Tom Cheesman (2007, p. 12) also argues against the paradigm of the inbetween. Following Ulrich Beck (2002), Cheesman (2007, p. 12) recognises a 'cosmopolitanisation' of German society. German-Turkish literature, in his view, arises from this 'cosmopolitanisation' while at the same time advancing it. In accordance with the study's title, Novels of Turkish German Settlement, Cheesman (p. 12) argues that "Turkishness" is intrinsic to the evolving "Germanness"' and thereby points to the need to reconsider what 'Germanness' comprises of. He further exemplifies the growing diversity of GermanTurkish literature regarding style, genre and content and points to the specific intertextual traditions developed.

Michael Hofmann (2013) goes one step further in the transnationalisation of German literary studies by proposing a German-Turkish literary criticism. Using a comparative approach, he establishes links between German, Turkish and German-Turkish literary texts and further analyses them through a cultural studies perspective.

In her study Rewriting Germany from the Margins, Petra Fachinger (2001) focuses on how respective literary texts use the mode of an 'oppositional aesthetic' to write their versions of Germany and national identity while at the same time rejecting their own marginalisation. Similarly, Tina Hartmann (2021) states that respective texts inscribe themselves into the canon and the literary centre from the societal margins and defines the German language to be the decisive marker for belonging to the national literature.

Therefore, a recognisable tendency in recent research is to consider literary texts that emerge in the context of migration and cultural contact to be part of the national canon rather than placing them outside or at the margins of German literature. However, the literary means of claiming space and shifting the boundaries of German literature as well as the participation of these texts in shaping and transforming the dominant discourse and society have not been studied exhaustively.

marginal to German-language literatures, but is part of them' (p. 142). 


\section{REWRITING AS A BOUNDARY SHIFTING LITERARY STRATEGY}

The emergence of the Bildungsroman at the end of the $18^{\text {th }}$ century can be linked to the historical specificities of political fragmentation and particularism in German-speaking territories at the time. In light of the lack of state unity, the desire for a German national identity manifested itself in the idea of a Kulturnation, which also emerges in Goethe's Wilhelm Meisters Lehrjahre (1795/96), generally perceived to be the founding text of the genre.Todd Kontje (2019) affirms the continuity of the Bildungsroman and proclaims its continuous significance in constructing a German national identity. And although genre theories lead a rather neglected existence in present literary criticism, the Bildungsroman has been able to maintain its relevance as a genre in recent research, which primarily deals with its contemporary modifications and innovations. ${ }^{1}$

In his essay, The Law of Genre, Jacques Derrida (1980) confirms the existence of genres for one thing while at the same time describing the impossibility to adhere to their borders. Disruptions and impurities interfere with the boundaries of the genre and thereby unsettle the law of genre while reproducing it at the same time. This paradox situation stems from the fact that the law of genre is based on a counter-law, a 'principle of contamination, a law of impurity, a parasitical economy' (Derrida \& Ronell, 1980, p. 59). Regarding texts and genres, Derrida, therefore, speaks of a 'participation without belonging' (ibid.). Every text participates in one or more genres 'yet such participation never amounts to belonging' (ibid., p. 65). He further discusses how the definitions of genres change over time and closes with a note on the subjectivity of taxonomies (ibid. p. 67 and 81). This also points to their historicity, which encouraged Ralph Cohen (1986) to jointly think of History and Genre.

Cohen understands the grouping of texts to a genre as a process that is influenced by the historical conditions and the intentions of the respective scholars (Cohen, 1986, p. 88). He is interested in the ways texts change a genre while still being associated with it as well. Cohen states that it is necessary to comprehend the process of change of a genre in order to understand its continued existence. He understands genres as historically constructed assumptions that pursue a social and an aesthetic purpose.

1 The recent comprehensive study A History of the Bildungsroman (Graham, 2019) is one example of the numerous renewals and the diversity of the genre. Apart from articles on more traditional forms such as the British, the French or the American Bildungsroman, the volume also includes contributions about postcolonial and LGBTQ* variants of the genre and alterations for children and adolescent or graphic novels. 
'Groupings arise at particular historical moments, and as they include more and more members, they are subject to repeated redefinitions or abandonment' (Cohen, 1986, p. 95).

Genre modifications can therefore be read as an expression of societal change and historical processes. Accordingly, in this study, genres are not understood as closed and static entities but as open categorisations that express social-historical processes and allow for change. Understanding genres as active classification systems with modifying boundaries allows to detach the Bildungsroman from its original context and apply it in different cultural and periodical backgrounds.

The concept of rewriting offers a suitable method to examine which elements of the traditional Bildungsroman are being transformed in the discussed novels and therefore receive new meanings. Rewriting is understood as a counter-discoursive writing and analysis concept, which changes or rewrites pretexts and thereby constructs a counter (hi)story. The appropriation of a genre is one form of rewriting, which holds marginalised voices against Eurocentric and hegemonic systems of representation, knowledge and thought (Osthues, 2017).

\section{DOUBLED MIMICRY: AYSEL ÖZAKIN'S DIE BLAUE MASKE AS AN IMITATED BILDUNGSROMAN}

Aysel Özakin, born 1942 in Urfa, was an established writer before coming to Germany as a political refugee following the military coup in Turkey in 1980. Compared to the short time that Özakin spent in Germany, her texts had a relatively significant impact in Germany (Adelson, 1997, p. 311). ${ }^{1}$ Originally published in Turkish as Mavi Maske a year before the German translation Die blaue Maske (The Blue Mask) by Carl Koß appeared in $1982 ;^{2}$ the novel follows a nameless first-person narrator on her journey from the Turkish province to Istanbul, Berlin and eventually Zurich, where she follows the traces and the husband of her old and by now deceased friend Dina.

The novel has been analysed regarding the hybridity of the protagonist's identity (Wägenbaur, 1995), her double existence and belonging to two worlds (Brunner, 1999, p. 193) and how it possibly sustains a victimising discourse around stereotypical images of the oppressed, Muslim woman (Mani, 2003; Wierschke, 1996). Azade Seyhan reads the text in the tradition of the Bildung-

1 Özakin felt her literary freedom constrained by the presuppositions of the German literary scene, expecting her work to deal with migration in one way or another and therefore left Germany to live in Cornwall in 1990 (Wierschke, 1996, p. 42).

2 Direct quotations from this edition will be my own translations and the citations will be identified through the acronym BL followed by the page number. 
sroman and states that it incorporates 'larger issues of exilic consciousness, the birth pangs and trauma of the women's movement of the 1960s and 1970s, and the radical reimagining of the state of nation' (Seyhan, 2001, p. 127).

Henckmann (1997, p. 47) analyses the novel regarding its doppelganger motif and observes it as a problem of demarcation and menacing disintegration connected to a feeling of the uncanny as it involves an experience of the self as part of the Other and vice versa. ${ }^{1}$ Doublings are a central motif in Özakin's novel, and they evoke the notion of mimicry coined by Homi K. Bhabha. In the colonial context, mimicry describes the mutual desire for the colonised to imitate the coloniser to seemingly stabilise the authority of the former and to overcome the inferiority of thelatter (Hermes, 2017, p. 185). Bhabha (1994, p. 122) describes it as 'the desire for a reformed, recognisable Other, as a subject of a difference that is almost the same, but not quite.' Therefore, an ambivalence is inherent to the concept since, 'in order to be effective, mimicry must continually produce its slippage, its excess, its difference' (Bhabha, 1994, p. 122). This difference stabilises the power relations but threatens them at the same time since the void between the original and the imitation opens up unconscious spaces of resistance and agency.

'The ambivalence of colonial authority repeatedly turns from mimicry - a difference that is almost nothing but not quite - to menace - a difference that is almost total but not quite' (Bhabha, 1994, p. 131).

The apparent adaptation to the authoritarian discourse through mimicry can be transferred to Özakin's text in two ways, namely to the scope of the figures and to the form of the texts. The protagonist is an author and her identity search begins during a book tour in Zurich. The form of the Bildungsroman is evoked by the travel motif and by the parallel narrative structure that oscillates between a framing story set in the narrator's experienced present and flashbacks into her past (Gutjahr, 2007, p. 48). The firstperson narrator comments retrospectively on her own development from a married teacher and mother in the Turkish province to a single mother in Istanbul, who ultimately lives alone as an author in Berlin. Her identity negotiation is embedded in the societal conditions of Turkey, Germany, and Switzerland. The form of the Bildungsroman is thus mimicked without being a complete imitation but rather a resemblance engendering a difference (Bhabha, 1994, p. 128).

1 Bhabha also refers to Freud's psychoanalytical concept of the uncanny to express the inevitable ambivalence of our multicultural world. The nation as a place of comfort and belonging interlaces with the uncanny and the menace emanating from the cultural Other. Bhabha further acknowledges that the Other cannot be located outside of the self but is always part of any cultural system and the discourse determined by this system (Bronfen, 2000, pp. X-XI). 


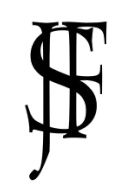

In Zurich, the protagonist runs into the husband of her friend Dina and learns that she has passed away. That triggers a process of a reminiscent quest, which leads to a doubling of the Bildungs-narrative. The narrator recounts her development as a young woman in Turkey and also searches for her current self. 'I imagine I'll meet myself soon as I get out of this labyrinth, my other, my changed self' (BL, p. 128).

The wedding as a typical ending, especially for the female Bildungsroman, is anticipated as failed in Özakin's text (Felski, 1989, p. 125). The reader learns that the protagonist was a married woman and employed as a teacher in the Turkish province. Using all her energy to meet the expectations of being an exemplary teacher and housewife while she really wants to be a writer (BL, p. 12), she hopes that her pregnancy will defeat the contradiction she carries inside (p. 14). When she told her husband about her wish to write, he advised her to do so but to leave her life as it is (p. 13).

It is at the beginning of her pregnancy that she meets Dina, the embodiment of a femme fatale, ${ }^{1}$ who belongs to a Europeanised and urban uppermiddle-class intellectual environment which the protagonist desires to be part of. Remembering how Dina names her Natasha in reference to Chekhov's Three Sisters when they first meet, the protagonist recounts:

'I felt that I really wanted to become someone else, to create a different life for myself' (BL, p. 18).

Like the identity search in the present, her initial development path in the past is also induced by a journey and an encounter with Dina. Throughout the novel, Dina is the point of reference that the protagonist compares herself to (Henckmann, 1997, p. 54). This becomes apparent when she feels the need to prove her new life beyond marriage and province to Dina (BL, pp. 130-31) or when she remembers: 'I wanted to write exactly like her, should I ever make it at all' (p. 182). That the desire for imitation is mutual becomes apparent when Dina suggests that the protagonist is wasting her youth and talent in the province, that she should stay in Istanbul to have an abortion and accompany her to live in Europe (BL, pp. 19-21).

Initially, Dina epitomises a westernised, liberated lifestyle and the urban intellectual class, something the protagonist strives to be part of. 'I didn't want to be like the common folk, I wanted to get out of it' (BL, p. 54). Dina becomes a projection surface for the protagonist's wish to escape her

1 Hanson and O'Rawe (2010, p. 1) state that the femme fatale 'is always beyond definition' and point to an aura of uncertainty and mystery surrounding such characters. This also applies to Dina, as she remains impalpable and secretive for the protagonist as well as for the reader. Classical attributes associated with a femme fatale, such as having a narcissistic attitude, being hypersexual and seductive and ultimately causing distress for people who get involved with her can be attributed to Özakin's construction of Dina as well. 
monotonous daily life and to live as an emancipated woman amongst leftist intellectuals, which is what she eventually does.

After leaving her marriage, the protagonist engages in a secret affair with the married communist activist Musa, which lasts for six years. Musa is pictured as someone who exploits the discourse of sexual liberation within the Left for his personal pleasure. The relationship reveals a strong inner conflict about her womanhood and her position as a woman in the Left and further discloses the external pressure the protagonist experiences. She is aware of the changed social expectations towards women in her new urban leftist intellectual environment and translates them into self-expectations, though having trouble complying with them. When recounting a memory of going home with Tekin, a man she sees after her affair with Musa has ended, the narrator reflects: 'I did not hesitate like one from the provinces and did not coquet about like a slut' (BL, p. 137). The new environment leads the protagonist to carry out a hyper-aware self-monitoring. How difficult it is to meet the fine line of acting sexually liberated but not inappropriate to the social norms becomes apparent when the protagonist attempts to claim sexual liberation for herself. She articulates wanting to meet other, unmarried men, and Musa tells her in response that she has 'something of a tart' about her (BL, p. 44). This passage underlines the patriarchal appropriation of sexual liberation as a male privilege and reinforces her inner struggle of being between two extremes, 'I wanted to be an independent woman and was yet perceived as a whore' (BL, p. 46). Accordingly, the narrator notes how the individual development is inextricably embedded in the social environment: "One cannot think of people detached from society"' (p. 135). The novel hence takes up the aspiration of the Bildungsroman to recount the development of an individual in close examination with the societal order (Gutjahr, 2007, p. 8).

The desire to imitate Dina is repeated in the narrated present, although the friends had grown apart when living in Berlin, mostly due to Dina envying the protagonist's success with writing (BL, p. 81). Through remembering the deceased friend, the conflict of the fitting of her inner and outer world is replicated in the present. It becomes apparent that by exploring Dina's past, the protagonist is actually searching for her own true self. This doubled identity search climaxes in the enhanced mimicry of Dina during the carnival in Zurich. 'Act like Dina, I whisper to myself, stop caring what others might think' (BL, p. 106). This repeated mimicry affirms and stabilises the authority of Dina and her way of life and thereby figuratively a lifestyle associated with the West. At the same time, a reflection process is initiated. 


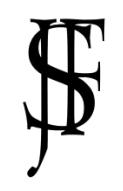

Журнал Фронтирных Исследований. 2021. No 2 | ISSN: 2500-0225

Пограничные исследования в современной европейской литературе | Doi: https://doi.org/10.46539/jfs.v6i2.291

In the flashbacks, the narrative process becomes a reminiscent one which allows the narrator to take on a critical and evaluating distance. Therefore, the idealised image of her friend that was formative to the protagonist's first development path is complemented in retrospect with Dina's failures. Memories of her suicide attempt at a young age (BL, p. 76), her multiple stays in psychiatric clinics (p. 190), her 'melancholy and loneliness' (p. 182) and her envy about the successful protagonist destabilise the authority that is initially attributed to Dina's identity.

Bhabha (1994, p. 80) describes mimicry also as a 'secret art of revenge' so that with an increasing demystification of Dina's lifestyle, a new function is ascribed to the imitation.

'Tonight! I want to transform myself into Dina, into Dina, who despised me for my feminine restraint and take revenge for this disdain!' (BL, p. 163).

The life paths of the friends, especially their dealings with men, are juxtaposed in hindsight. The inherent ambiguity of Dina's representation allows for a subsequent revaluation of her once idealised lifestyle,whereby Weber (2009, p. 65) notes the narrator's tendency to devalue Dina's story in favouring her own. Through the simultaneous urge to again mimic Dina, an ambivalence occurs, which indicates that the protagonist admits the Other, which can never be located outside of us (Bronfen, 2000, p. XI), a place in her self. 'Carnival, where the mask and suppressed self become one' (BL, p. 163). The protagonist starts to talk in her friend's voice (p. 165). When wearing the title giving blue mask, Dina's husband compliments her and calls her a femme fatal, invoking the imagery connected to Dina. (p. 171). Therefore she indeed 'almost but not quite' (Bhabha, 1994, p. 129) becomes Dina.

Struve (2017, p. 18) notes that Bhabha's concept of mimicry holds the possibility of agency and that this empowerment is possible not in spite but because of the presence of the Other within the self. The mimicry through the mask is setting the protagonist in strangeness to herself, which allows her to access her self and her Other, leading to the demasking of any homogeneous identity constructions. The protagonist eventually frees herself from the desire of the mimicry and takes the mask off (BL, p. 196).

It is indicated that the protagonist went through a second development path and validated her identity, at least temporarily, beyond the mask and the overpowering role model Dina. The protagonist decides to leave Zurich but is uncertain where to (BL, p. 195). The open ending of the text refers to the development of identity as something processual and open, as a 'continued journey' (Weber, 2009, p. 73). The classical structure of the protagonist's final societal reintegration in the traditional Bildungsroman 
is thereby subverted. At the end of her journey, there is no closed or fixed identity but the discovery of a self that is accepting of its contradictions.

The protagonist's personal conflict around a coherent self is framed by an identity crisis of the Turkish nation. 'The Turkish society is not consolidated; it has not found itself yet' (BL, p. 188). After the founding of the Turkish Republic in 1923, Mustafa Kemal Atatürk mandated numerous reforms to establish a secular, westernised nation-state. Reiterated by prime minister Adnan Menderes, who announced in 1950 that he would turn Turkey into a 'little America' (Schonfield, 2015, p. 70), Özakin's text depicts the imitation of the West as a point of conflict within the Left, expressed in dialogues unassociated to any characters. 'Turkish intellectuals are on their own. They can neither identify with the Orient nor with the Occident'.

'We don't have any alternative to the westernisation'. 'The West disdains us because we're imitating it' (BL, p. 188-89; see also pp. 53-54 and p. 139).

The identity crisis of the nation resembles the protagonist's own struggle to navigate between mimicking western ideals and fulfilling (self)expectations. Therefore, her journeys of development are permeated by a layer that surpasses the personal.

The national crisis culminates in the 1980 military coup resulting in the political persecution of the protagonist and her emigration to Berlin. This explains the impossibility of a traditional Bildungsroman ending, as 'for the "exiled" hero/ine, there is no return' (Seyhan, 2001, p. 127). Her affiliation to the Left is an important identity marker for the protagonist. As it becomes the reason why the motherland is rejecting her, Turkey becomes a 'lost nation' (Seyhan, 2001, p. 134). The memory of her deceased friend's life, which was marked by mental illness, is therefore framed by a 'psychosocial biography of the homeland' (ibid.).

The doubled mimicry can be located in the characters as well as on the formal level. The protagonist draws her strength and agency from the difference produced when mimicking Dina since ' $[\mathrm{m}]$ imicry conceals no presence or identity behind its mask' (Bhabha, 1994, p. 126). The protagonist rather develops a way of life that resembles Dina's but goes beyond that. This becomes most apparent in her desire to mimic Dina's writing but eventually creating her own style that proves to be more successful.

'She embarrassed me with her free, modern and adventurous life, whereas I awoke her doubts through my grounded being' (BL, p. 182).

'The menace of mimicry is its double vision which in disclosing the ambivalence of colonial discourse also disrupts its authority' (Bhabha, 1994, p. 126). 
The doubled mimicry reveals the ambivalence of the western dominance on a personal and a political level and fractures its authority to an extent on a personal level. The protagonist finds access to the uncanny in herself and thereby disturbs the demand of a homogeneous subject inherent to the nation. Through mirroring the identity crisis and the mimicry on the level of the nation, the text can be interpreted as a plea against exclusion and discrimination. This is especially articulated in the updated scheme of the Bildungsroman since the traditional return and societal reintegration of the heroine is prevented precisely because of such exclusions.

Özakin's mimicry of the Bildungsroman proves to be an effective rewriting strategy, as the imitation produces a difference, which rebuts the Euro- and androcentrism of the traditional form. Text and author claim space in the national canon by appropriating the genre while at the same time shifting their traditional boundaries.

\section{HISTORIOGRAPHIC METAFICTION: EMINE SEVGI ÖZDAMAR'S DIE BRÜCKE VOM GOLDENEN HORN AS A PARODISTIC BILDUNGSROMAN}

Emine Sevgi Özdamar was born in 1946 in Malatya and initially moved to Berlin as a factory worker for two years in 1965. She then completed training as an actress in Istanbul and left Turkey again for Germany after the 1971 military coup. Özdamar's texts have been awarded several prizes, translated into many languages and researched extensively. ${ }^{1}$ Analyses of her work tend to focus on the hybridity of its language and the textual strategy of literal translation (see e.g. Ergin, 2013; Seyhan, 2001; Yildiz, 2012) and further prioritise the transnational and intercultural quality of her texts, emphasising the multi-layered identities presented, which are constructed within a pluralistic understanding of cultures (see e.g. Boa, 2006; Brunner, 2003; Ege, 2016; Johnson, 2001; Krause, 2000).

The plot of Die Brücke vom Goldenen Horn (The Bridge of the Golden Horn) is set between 1966 and 1975 and is mainly located in Berlin, Istanbul and Paris, cities in which the nameless first-person narrator discovers communism and her sexuality and follows her wish to become a theatre actress. ${ }^{2}$ The individual formation of the protagonist is embedded in the political events of the time and is narrated against the backdrop of the New Left movement and the Turkish military coup of 1971. Both Beverly Weber (2010) and Ortrud Gutjahr (2007) have interpreted the novel as a sexual coming-of-age narrative and an intercultural Bildungsroman, respectively.

1 For a selective bibliography see Dayıŏlu-Yücel (2016).

2 I will use the English translation by Martin Chalmers (Özdamar, 2007) and direct quotations will be identified by the acronym GH followed by the page number. 
Elizabeth Boa (2006, pp. 536-37) describes the protagonist in reference to Goethe and Grimmelshausen as 'Wilhelmine Meister' and 'Simplicissima', evoking both the genre of the Bildungsroman and the picaresque novel. This points to the parodistic character of the text, which is reinforced through its ironic-picaresque narrative style.

The parody of the Bildungsroman and the numerous intertextual references point to a certain metafictionality inherent to the novel. Paired with the many historical references occurring in the text, this evokes Linda Hutcheon's concept of historiographic metafiction. Historiographic metafiction means the reworking of the past through intertextual parody so that the respective texts are 'at once metafictional and historical in its echoes of the texts and contexts of the past' (Hutcheon, 1989, p. 3). Preoccupied with the question of how we come to know our past in the present, Hutcheon $(1989$, p. 10) makes a connection to the literary, as "we can only "know" that past today through its texts' and further challenges the possibility of objective historical knowledge and true meaning. ${ }^{1}$

To finance her visit to drama school, Özdamar's protagonist decides to find work in Germany. Therefore the novel starts off with a journey, a topos typical to the genre of the Bildungsroman. The protagonist has three ambitions, according to Boa (2006, p. 535):

'to read, write and perform linguistically; to lose her virginity; to become politically active.'

Even though negated by Özdamar herself (Gutjahr, 2008), the secondary literature has repeatedly suggested that her work has an autobiographical foundation (Boa, 2006; Gutjahr, 2016; Hofmann, 2006). In an interview, Özdamar said that when writing 'one is always using masks and one figure always has three figures inside, you take one from life, one from the theatre, one from the film and out of it becomes one figure' (Wierschke, 1996, p. 252, my translation). This technique of layering reality and fiction is recognisable in some of the novel's characters who are inspired by real persons, such as the communist hostel warden who introduces her to Brecht and the Berliner Ensemble (Horrocks \& Kolinsky, 1996, p. 45) or a lover who studied film with Pasolini and with whom she lived in a film-commune (Dayığlu-Yücel \& Özdamar, 2016, p. 81). To the question of whether her novel is very authentic, Özdamar answered:

'Yes, of course, one says that even the most disguised figures in theatre are autobiographical. Of course, autobiographical things are always incorporated, but everything becomes an adventure' (Wierschke, 1996, p. 264, my translation).

1 When developing her concept, Hutcheon refers to Hayden White's (1974) claim that the writing of history is also a narrative act and that historical texts are always partly fiction. 
Considering these remarks and the parallels between narrator and author, such as their affection for theatre, the migration to Germany and their political prosecution, allows the assumption that a doubling of the real and the fictional is also practised in writing the protagonist. The amalgamation of fiction with autobiographical and historical elements is assessed as a deliberately employed literary means. The text thereby situates itself in a historical discourse without giving up its autonomy as fiction (Hutcheon, 1989, p. 4). The mode of the historiographic metafiction allows for a subjective but authenticated female perspective on the work migrations to Germany and the New Left.

The protagonist takes on a factory job in Berlin and lives in a hostel so that in addition to her personal experience, the stories of other female workers from Turkey are narrated as well. This purveys a broader impression of Turkish migrant women in Germany, for example, when the protagonist recounts her housemates' reasons for relocating. There are two lesbian cousins who want to go to university after working in the factory (GH, p. 11); there is Rezzan who, like the protagonist, wants to become an actress (p. 13); a woman who is earning money for a plane ticket to the U.S. to get married to an American soldier, and another who needs money for a breast reduction (p. 18). These are depictions of independently acting women who are in control of their lives. The text thereby offers a representative counterweight to the prevailing view that hardly any female workers came to Germany in the 1960s and 1970s and if they did only as part of a family reunion (Weber, 2010, p. 39).

Apart from recounting her own experiences with men, the narrator recounts those of other Turkish women as well. It is for example, when she remembers how Angel loses her virginity (GH, p. 42). She further describes the contradictions among the women in the hostel. While 'Rezzan and Gül went into the night with Mobil Oil and Salim, drank Coffee in the Old Vienna early in the morning and came straight to the factory from there' (p. 63), another group of women warns them '"You'll end up whores!"' (p. 25) when they go out.

In the public and academic discourse in Germany at the time, a stereotypical representation of Turkish and German-Turkish women as oppressed by patriarchal family structures and male dominance executed in the name of Islam was prevalent. Such depictions construct Muslim women as the Other of the emancipated western woman, pointing to the 'irreducible ideological nature of every representation - of past or present' (Hutcheon, 2002, p. 51). ${ }^{1}$

1 Examples of the prevalent stereotypical images of Turkish migrants in academic discourses mentioned by Weber (2010) are studies by Baumgartner-Karabak \& Landsberger (1978) and Meske (1983). Both have the basic intention to improve the conditions for Turkish women in Germany but examine their lives with a western gaze, imposing West German feminist solutions and notions of 
By centring female figures and constructing them as active and self-determined subjects, Özdamar's text conveys an alternative and broadened image of the heterogeneous Turkish migrant community in Germany in the late 1960s.

The protagonist's political formation provides an expanded female and transnational historical perspective on the New Left. The infusion of the text with external facts regarding Turkey's daily politics and Europe in the 1960s affirms the existence of official histories. Simultaneously, the authority of historical knowledge is challenged by adding a layer of subjectivity and personal experience, providing alternative representations of official histories. For instance, it is when the protagonist recounts the Berliner 1968 student movement's protest and adds that among them were also Turkish protesters. 'And soon I also got to know Turkish chickens, who walked with the German chickens on the streets and spoke the same chicken language' (GH, p. 119). Here, national affiliations are secondary; sharing the same 'chicken language' points to the common goals of anti-imperialism, anti-capitalism and antifascism of the political left. ${ }^{1}$

The prevalent historical narratives situate the German New Left primarily in West German academic elites, and Ernest Schonfield (2015, p. 68) confirms: 'German historians have, until recently, neglected the theme of migrant political activism.' Özdamar's text provides a representation diverging from the mainstream by situating figures of the work migrations next to the usual prominent protagonists of the 1968 movement. References to fascist Spain under Franco, Greek communists fleeing the military junta, Che Guevara's death or the execution of Turkish student leader Deniz Gezmiş suggest the transnational character of the leftist movement, fighting a similar fight in different localities. Schonfield $(2015$, p. 67) reads Özdamar's novel in this context as 'bear[ing] witness to historical events which were shared across national boundaries.' The text incorporates intertextual references to Turkish and Ottoman literary traditions while at the same time referring extensively to a European cultural and literary canon. These 'intertextual echoes' (Hutcheon, 1989, p. 22) have a mediating and connecting function within the transnational leftist movement.

Apart from demonstrating the New Left's transnational interdependence, Özdamar also inscribes the perspective of a woman into the Turkish leftist movement. The novel is set within a period where the Turkish Left,

emancipation on them and thereby conveying an impression of German women saving their Turkish 'sisters.' Rita Chin (2010) discusses the relation of Turkish women with West German feminists regarding the economic interests of the latter's scholarly activity and the concurrent confirmation of their own manner of living as the more desirable and appropriate one.

1 Özdamar picks up the imagery of the speaker of the Berlin Senator Hanns-Peter Herz, who referred to student protesters as chickens in April 1967 ('Nein, nein, nein', 1967). 
though fragmented, gained strength and influence until the 1980s coup prohibited all political activity and especially dispersed leftist organisations (Durgun, 2015). Women's rights, however, were omitted from the left agenda in Turkey. Before feminism was established as independent from any other political movement after the 1980s coup, the left-wing movement was shaped by a male framework, allowing women to participate in the greater socialist revolution but not granting any room to negotiate 'the women question' (Tekeli, 1995, p. 13). The male dominance of the Turkish Left is reflected, for instance, when the protagonist gets a somewhat patronising answer when asking the hostel warden if she can become a communist too - "Yes, Sugar, [...] Marx is too difficult for you, but perhaps you can read Engels"' (GH, p. 67) - or when she remarks that no one asks her opinion when discussing political subjects (p. 178).

The protagonist is also confronted with the movement's claim of sexual liberation, a crucial point on the Left's agenda at that time. Declarations like '[f]rom now on we share everything. We want to sleep with her too' $(\mathrm{GH}$, p. 237), point to the patriarchal reframing of increased sexual freedom as sexual availability for men. After her own sexual coming-of-age in Berlin and Paris, the protagonist tries to convince peasant women in eastern Turkey to use contraception and advocates for their right to orgasm (p. 210). She uses the space of the leftist groups to actually perform a specific gender identity by means of parody. Since the bars where leftists meet are male-dominated areas, her own presence reminds her of the sex workers called 'consumatrists', who are the only women around. By consciously acting out the role of a sexworker, "I have come as a consumatrist"' (p. 165), the protagonist humorously creates awareness towards the socially constructed restrictions functioning in a binary framework that regulates access to specific spaces.

By situating the protagonist within the Turkish Left, the novel contributes significantly to widening the discourse on women's roles in the movement. Pointing to the omission of women issues on their agenda, Fatma Berktay (1995, p. 250) states that '[i]t is therefore difficult even to find adequate written documentation on the attitude of the Left to women before 1980. Özdamar thus fills a gap by narrating a self-determined woman's individual development path within the Turkish Left. A characteristic of historiographic metafiction is to tell the stories of those whose voices were not heard during the depicted events (Hutcheon, 2002, p. 49) and to challenge the idea of objective knowledge by calling attention to the silenced histories by further asking which events of the past are given meaning by constructing them as facts (ibid., p. 54).

The protagonist's enthusiasm for theatre evokes the ideal to educate oneself through theatre, formulated in Goethe's founding text of the genre. 
While the theatre is more of a transitional stage towards a new social role for Wilhelm Meister, Özdamar's protagonist is certain: '"Theatre is my life [...]"' (GH, p. 4). Leftist groups and cultural institutions experience brutal crackdowns in the course of the right-wing military coup in 1971 in Turkey so that the protagonist's way of life is profoundly disturbed. Her detention and the impossibility of performing on stage let her fall silent, and she eventually decides to go back to Berlin. The violence carried out in the name of the Turkish nation-state deprives the protagonist of living her identity. Therefore, the reintegration of the individual into society as the typical ending of the traditional Bildungsroman can not be realised. Emigration becomes a necessity in order to reclaim her language and thereby her artistic and political identity.

Overall, the text can be read as a parody of the traditional Bildungsroman. While the genre serves as a frame for the expansion of the national cultural memory, its parodistic appropriation serves as a literary strategy to claim space in the German national canon.

\section{Intertextual parody of canonical classics is one mode of reappropriating and reformulating - with significant changes - the dominant white, male, middle- class, European culture. It does not reject it, for it cannot. It signals its dependence by its use of the canon, but asserts its rebellion through the ironic abuse of it. (Hutcheon, 1989, p. 12)}

The text insists on its fictionality while intertwining with lived realities of the past. It therefore fills in a gap in the national cultural memory in respect to the work migrations and the leftist student movement from a female German-Turkish perspective. At the same time, women are inscribed in the biography of the Turkish Left. A parodistic rewriting can be understood as an ironic commentary, filling in the blind spots of the pretext (Osthues, 2017, p. 219). In this sense, the modus of the historiographic metafiction pervading the text provides a counter-(hi)story to the cultural hegemony of the German and European literary canon and thereby shifts and expands its boundaries.

\section{CONCLUSION}

This study aimed to identify literary means employed to oppose the exclusion or marginalisation of literatures of migration from the national canon. It was therefore analysed how the two discussed German-Turkish novels use the strategy of rewriting to inscribe themselves into the canonical genre of the Bildungsroman, demanding discursive participation on an artistic and aesthetic level, and thereby claiming space in the German canon while shifting its boundaries at the same time. Under the methodical premise of 


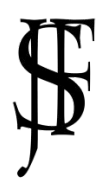

Журнал Фронтирных Исследований. 2021. No 2 | ISSN: 2500-0225

Пограничные исследования в современной европейской литературе | Doi: https://doi.org/10.46539/jfs.v6i2.291

understanding genres as active classification systems with modifying boundaries, two forms of rewriting could be identified, which both stand in a conflicting relation with the concept of the nation. While Özakin mimics the genre, Özdamar applies a parodistic rewriting to the Bildungsroman.

In Özakin's novel, the protagonist's mimicry of her friend Dina, who epitomises the western way of life, is mirrored on the level of the Turkish nation. Denoting how the dominance of the West permeates the personal and the political sphere, mimicry proved to be an effective strategy to undermine the authority of both Dina and the West. The protagonist is able to validate her identity temporarily by discovering the Other in her self and allowing for its presence. The conveyed processual construction of identity is disrupting the nation's desire of consistent and homogeneous subjects. Applied to the formal level of the text, mimicry turned out to be a fruitful form of rewriting, as the imitation produces a difference, which subverts the Euro- and androcentrism of the Bildungsroman, while still participating in the genre and hence contributing to its actualisation.

Özdamar's parodostic rewriting of the genre can be read as a complementary comment to the national cultural memory. The historiographic metafictional quality of the texts allows for it to maintain its authority as fiction while representing historical events at the same time. The recounts of the work migrations to Germany and the transnational leftist student movement are authenticated by the autofictional mode which is used as a deliberate literary strategy. Özdamar's text acknowledges the existence of official histories but simultaneously challenges the authority of historical knowledge by adding a layer of subjectivity and personal experience, providing historical representations that have been omitted of dominant historical discourses. As stated by Hutcheon $(1989$, p. 6), ' $[\mathrm{t}] \mathrm{o}$ parody is not to destroy the past; in fact, to parody is both to enshrine the past and to question it.' While the authors apply different forms of rewriting the Bildungsroman, the study shows that they both deny the protagonists the typical societal reintegration at the end of the novels. Fachinger (2001, p. 21) observes that the modification or omission of a classic genre component directs attention towards it and charges it with new meaning. In the classical Bildungsroman, society and its norms are approved by the successful reintegration of the hero (Moretti, 1987, p. 24). The subversion of the original plot structure therefore points to the repressive and exclusionary conditions of the homeland that makes the reintegration impossible. The nation is therefore not affirmed but critically questioned regarding its societal structures.

Although Özdamar's and Özakin's texts voice criticism towards the German society, it is primarily the Turkish nation that is condemned. The military coups depicted in both texts point to a violent crisis of the nation, 
partially initiated by its lack of accepting the Other within the self. Both protagonists experience violence and oppression in the name of the nation, which leads to their emigration since they cannot live their identities. The novels question the original idea of the nation by criticising its claim for homogeneity. Instead of the homeland, they find alternative possibilities of belonging in political and artistic groups, which are characterised by openness and heterogeneity. The criticism and rejection of the idea of the nation is first and foremost to be understood as a plea for a diverse togetherness and parallel existence that speaks out against exclusion and discrimination.

Drawing on Victor Turner's re-discovery of the notion of liminality, initially developed in relation to rites of passage in tribal communities but extended in its application to entire societies, the concept has proven prolific for border studies (Thomassen, 2018). It 'captures in between situations and conditions characterized by the dislocation of established structures, the reversal of hierarchies, and uncertainty about the continuity of tradition and future' (Horvart, Thomassen, \& Wydra, 2018, p. 2). Therefore, it can be argued that the German literary canon of the 1990s and early 2000s partially found itself in such a liminal state, as the belonging of texts arising in the context of migration and cultural contact was negotiated and discussed in the respective secondary literature.

By employing the literary means of rewriting, the studied texts inscribe themselves into the canonical genre of the Bildungsroman and hence claim space in German national literature. The discussed German-Turkish novels point to the continuous relevance of the Bildungsroman in constructing German national identities. At the same time, this leads to an ambivalence since the novels question national categories and refer to their potentially repressive characters. This again points to the notion of liminality and its inherent ambivalence. As a condition of the transitional, liminality threatens established hierarchies and structures but at the same time suggests 'a vital moment of creativity, a potential platform for renewing the societal makeup' (Mälksoo, 2018, p. 226). By reformulating and adapting the boundaries of the genre in a subversive way, the analysed texts express the need to renegotiate the nation as a concept as well as its demand for homogeneity. By voicing German-Turkish as well as other pluralistic identities and inscribing them into the national cultural memory and literary canon, the authors anticipate the societal shifts that led to the official recognition of Germany as a nation of immigration in 2001. 


\section{References}

Adelson, L. A. (1997). The Price of Feminism: Of Women and Turks. In P. Herminhouse \& M. Mueller (Eds.), Gener and Germanness. Cultural Productions of Nation (pp. 305-319). Providence, Oxford: Berghahn Books.

Adelson, L. A. (2000). Touching Tales of Turks, Germans, and Jews: Cultural Alterity, Historical Narrative, and Literary Riddles for the 1990s. New German Critique, 80, 93-124. doi: $10.2307 / 488635$

Adelson, L. A. (2003). Against Between: A Manifesto. New Perspectives on Turkey, 28-29, 1936. doi: 10.1017/S0 896634600006099

Adelson, L. A. (2005). The Turkish Turn in Contemporary German Literature. Towards a New Critical Grammar of Migration. New York: Palgrave Macmillan.

Anderson, B. (2006). Imagined Communities. Reflections on the Origin and Spread of Nationalism (Revised Ed). London, New York: Verso.

Baumgartner-Karabak, A., \& Landsberger, G. (1978). Die verkauften Bräute. Türkische Frauen zwischen Kreuzberg und Anatolien [The Sold Brides. Turkish Women between Kreuzberg and Anatolia]. Reinbeck: Rowohlt. (In German).

Beck, U. (2002). The Cosmopolitan Society and Its Enemies. Theory, Culture \& Society, 19(1), 17-44. doi: 10.1177/026327640201900101

Berktay, F. (1995). Has Anything Changed in the Outlook of the Turkish Left on Women? In S.. Tekeli (Ed.), Women in Modern Turkish Society. A Reader (pp. 250-262). London: Zed Books.

Bhabha, H. K. (1994). The Location of Culture. London, New York: Routledge Classics.

Boa, E. (2006). Özdamar's Autobiographical Fictions: Trans-National Identity and Literary Form. German Life and Letters, 59(4), 526-539. doi: 10.1111/j.1468-0483.2006.00366.x

Brennan, T. (1990). The national longing for form. In H. K. Bhabha (Ed.), Nation and Narration (pp. 44-70). London, New York: Routledge.

Bronfen, E. (2000). Vorwort [Foreword]. In E. Bronfen, M. Kessler, P. M. Lützeler, W. Graf Vitzthum, \& J. Wertheimer (Eds.), Die Verortung der Kultur [The location of the culture] (p. IX-XIV). Tübingen: Stauffenburg. (In German).

Brunner, M. E. (1999). Der Fremde erlaubt dir, du selbst zu sein, indem er aus dir einen Fremden macht': Ein Porträt der Autorin Aysel Özakin [The Stranger Allows You to Be Yourself by Making You a Stranger': A Portrait of Author Aysel Özakin]. Arcadia, 34(2), 189-204. (In German).

Brunner, M. E. (2003). Literarische Mehrsprachigkeit und Transkulturalität. Der Dialog zwischen den Kulturen und das Echo von Mimikry und sprachlicher Hybridität im Werk deutsch-türkischer Autorinnen [Literary Multilingualism and Transculturality. The Dialogue between Cultures and the Echo of Mimicry and Linguistic Hybridity in the Work of German-Turkish Women Authors]. Linguistica Antverpiensia, New SeriesThemes in Translation Studies, 2, 115-128. (In German).

Cheesman, T. (2007). Novels of Turkish German Settlement. Cosmopolite Fictions. Rochester, New York: Boydell \& Brewer, Camden House. 
Chin, R. (2010). Turkish Women, West German Feminists, and the Gendered Discourse on Muslim Cultural Difference. Public Culture, 22(3), 557-581. doi: 10.1215/08 9923632010-009

Cohen, R. (1986). History and Genre. Neohelicon, 13(2), 87-105.

Dayığlu-Yücel, Y. (2016). Auswahlbibliografie [Selection bibliography]. In Y. Dayığlu-Yücel \& O. Gutjahr (Eds.), Text+Kritik. Emine Sevgi Özdamar (pp. 89-95). München: Richard Boorberg Verlag. (In German).

Dayığlu-Yücel, Y., \& Özdamar, E. S. (2016). 'Das mutigste Mädchen, das diese steile Straße hochläuft'. Gespräch mit Emine Sevgi Özdamar über ihre Begegnungen mit Schriftstellern (August 2015) ['The bravest girl walking up this steep road'. Interview with Emine Sevgi Özdamar about her encounters with writers (August 2015)]. In Y. Dayığlu-Yücel \& O. Gutjahr (Eds.), Text+Kritik. Emine Sevgi Özdamar (pp. 80-88). München: Richard Boorberg Verlag. (In German).

Derrida, J., \& Ronell, A. (1980). The Law of Genre. Critical Inquiry, 7(1), 55-81. doi: $10.1086 / 448088$

Durgun, S. (2015). Left-Wing Politics in Turkey: Its Development and Problems. Arab Studies Quarterly, 37(1), 9-32. doi: 10.13169/arabstudquar.37.1.0009

Ege, M. (2016). Stadt und Sprache als Transiträume bei Emine Sevgi Özdamar. Interkulturelle Einblicke in narrative Topografien [City and Language as Transit Spaces in Emine Sevgi Özdamar. Intercultural Insights into Narrative Topographies]. In Y. Dayığlu-Yücel \& O. Gutjahr (Eds.), Text+Kritik. Emine Sevgi Özdamar (pp. 37-47). München: Richard Boorberg Verlag. (In German).

Ergin, M. (2013). Emine Sevgi Özdamar's Translingual Poetics in Mutterzunge. Seminar: A Journal of Germanic Studies, 49(1), 20-37. doi: 10.3138/sem.49.1.20

Esselborn, K. (2009). Neue Zugänge zur inter/transkulturellen deutschsprachigen Literatur [New approaches to inter/transcultural German-language literature]. In H. Schmitz (Ed.), Von der nationalen zur internationalen Literatur. Transkulturelle deutschsprachige Literatur und Kultur im Zeitalter globaler Migration [From National to International Literature. Transcultural German-Language Literature and Culture in the Age of Global Migration] (pp. 43-58). Amsterdam, New York: Rodopi. (In German).

Fachinger, P. (2001). Rewriting Germany from the Margins. 'Other' German Literature of the 1980s and 1990s. Montreal \& Kingston: McGill-Queen's University Press.

Felski, R. (1989). The Novel of Self-Discovery: Integration and Quest. In Beyond Feminist Aesthetics. Feminist Literature and Social Change (pp. 122-153). London: Hutchinson Radius.

Graham, S. (Ed.). (2019). A History of the Bildungsroman. Cambridge: Cambridge University Press.

Grjasnowa, O. (2019). Privilegien [Privileges]. In F. Aydemir \& H. Yaghoobifarah (Eds.), Eure Heimat ist unser Albtraum [Your homeland is our nightmare] (pp. 130-139). Berlin: Ullstein fünf. (In German). 


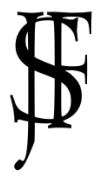

Журнал Фронтирных Исследований. 2021. No 2 | ISSN: 2500-0225

Пограничные исследования в современной европейской литературе | Doi: https://doi.org/10.46539/jfs.v6i2.291

Gutjahr, O. (2007). Einführung in den Bildungsroman [Introduction to the Bildungsroman].

Darmstadt: Wissenschaftliche Buchgesellschaft.

Gutjahr, O. (2008). Emine Sevgi Özdamars Die Brücke vom Goldenen Horn. Ein interkultureller Bildungsroman [Emine Sevgi Özdamar's The Bridge of the Golden Horn. An Intercultural Bildungsroman]. In R. Riedner \& S. Steinmann (Eds.), Alexandrinische Gespräche [Alexandrian Talks] (pp. 125-140). München: München Iudicium. (In German).

Gutjahr, O. (2016). Inszenierungen eines Rollen-Ich. Emine Sevgi Özdamars theatrales Erzählverfahren [Stagings of a Role-It. Emine Sevgi Özdamar's theatrical narrative process]. In Y. Dayığlu-Yücel \& O. Gutjahr (Eds.), Text+Kritik. Emine Sevgi Özdamar (pp. 8-18). München: Richard Boorberg Verlag. (In German).

Haines, B. (2008). The Eastern Turn in Contemporary German, Swiss and Austrian Literature. Debatte: Fournal of Contemporary Central and Eastern Europe, 16(2), 135-149. doi: 10.1080/09651560802316899

Hanson, H., \& O’Rawe, C. (2010). Introduction: 'Cherchez la femme'. In H. Hanson \& C. O’Rawe (Eds.), The Femme Fatale: Images, Histories, Contexts (pp. 1-8). Houndsmills: Palgrave Macmillan.

Hartmann, T. (2021). Deutsch als Literaturheimat. Warum Literatur multilingualer Autorinnen und Autoren einfach deutsche Literatur ist [German as a Literary Homeland. Why Literature by Multilingual Authors is Simply German Literature]. In D. Syrovy (Ed.), Discourses on Nations and Identities (pp. 355-369). Berlin, Boston: De Gruyter. (In German).

Henckmann, G. (1997). Wo Maske und unterdrücktes Ich eins werden’ Zum Motiv der Doppelgängerin in Aysel Özakins Die blaue Maske [Where Mask and Repressed Ego Become One' On the Motif of the Doppelganger in Aysel Özakin's The Blue Mask]. In M. Howard (Ed.), Interkulturelle Konfigurationen. Zur deutschsprachigen Erzählliteratur von Autoren nichtdeutscher Herkunft [Intercultural Configurations. On Germanlanguage narrative literature by authors of non-German origin] (pp. 47-61). München: iudicium verlag. (In German).

Hermes, S. (2017). Mimikry [Mimicry]. In D. Göttsche, A. Dunker, \& G. Dürbeck (Eds.), Handbuch Postkolonialismus und Literatur [Handbook Postcolonialism and Literature] (pp. 185-187). Stuttgart: Springer. (In German).

Hofmann, M. (2006). Der verfremdete Blick des weiblichen Schelms: Emine Sevgi Özdamar als Erzählerin des Überschreitens [The alienated gaze of the female prankster: Emine Sevgi Özdamar as a narrator of transgression]. In Interkulturelle Literaturwissenschaft. Eine Einführung [Intercultural Literary Studies. An introduction]. Paderborn: Wilhelm Fink. (In German).

Hofmann, M. (2013). Deutsch-türkische Literaturwissenschaft [German-Turkish literary studies]. Würzburg: Könighaus \& Neumann. (In German).

Horrocks, D., \& Kolinsky, E. (1996). Living and Writing in Germany. Emine Sevgi Özdamar in Conversation with David Horrocks and Eva Kolinsky. In D. Horrocks \& E. Kolinsky (Eds.), Turkish Culture in German Society Today (pp. 45-54). Providence, Oxford: Berghahn Books. 
Horvart, A., Thomassen, B., \& Wydra, H. (2018). Introduction. Liminality and the Search for Boundaries. In A. Horvart, B. Thomassen, \& H. Wydra (Eds.), Breaking Boundaries. Varieties of Liminality (pp. 1-8). New York, Oxford: Berghahn Books.

Hutcheon, L. (1989). Historiographic Metafiction. Parody and the Intertextuality of History. In P. O’Donnell \& R. C. Davis (Eds.), Intertextuality and contemporary American fiction. Baltimore: Johns Hopkins University Press.

Hutcheon, L. (2002). The Politics of Postmodernism. Routledge.

Johnson, S. (2001). Transnational Ästhetik des türkischen Alltags: Emine Sevgi Özdamar's Das Leben ist eine Karawanserei [Transnational Aesthetics of Turkish Everyday Life: Emine Sevgi Özdamar's Life is a Caravanserai]. The German Quarterly, 74(1), 37-57. doi: 10.2307/3 072 814. (In German)

Kontje, T. (2019). The German Tradition of the Bildungsroman. In S. Graham (Ed.), A History of the Bildungsroman (pp. 10-32). Cambridge: Cambridge University Press. doi: $10.1017 / 9781316479926$

Krause, F. (2000). Shadow Motifs in Emine Sevgi Özdamar's Die Brücke vom Goldenen Horn: A Corrective to the Limitations of Current Debates on Inter-Cultural Issues. fournal of Contemporary Central and Eastern Europe, 8(1), 71-86. doi: 10.1080/713659892

Mälksoo, M. (2018). The Challenge of Liminality for International Relations Theory. In A. Horvart, B. Thomassen, \& H. Wydra (Eds.), Breaking Boundaries. Varieties of Liminality (pp. 226-243). New York, Oxford: Berghahn Books. doi: 10.1017/ S0 260210511000829

Mani, V. B. (2003). The Good Woman of Istanbul: Emine Sevgi Özdamar's Die Brücke vom Goldenen Horn. In P. M. Lützeler \& S. K. Schindler (Eds.), Gegenwartsliteratur. Ein germanistisches Fahrbuch. Schwerpunkt Multikultur [Contemporary Literature. A German Studies Yearbook. Focus on multiculture] (pp. 29-57). Stauffenburg Verlag.

Meske, S. (1983). Situationsanalyse türkischer Frauen in der BRD [Situation Analysis of Turkish Women in the FRG]. Berlin: EXpress Edition. (In German).

Moretti, F. (1987). Ways of the World. The Bildungsroman in European Culture (A. Sbragia, Ed.). London: Verso.

Nein, nein, nein [Der Spiegel]. (1967, June 4). Retrieved from https://www.spiegel.de/ politik/nein-nein-nein-a-92b28340-0002-0001-0000-000 046251 957?context=issue

Osthues, J. (2017). Rewriting. In D. Göttsche, A. Dunker, \& G. Dürbeck (Eds.), Handbuch Postkolonialismus und Literatur [Handbook Postcolonialism and Literature] (pp. 216219). Stuttgart: Springer. (In German).

Özakin, A. (1989). Die blaue Maske [The blue mask]. Frankfurt am Main: Luchterhand Literaturverlag. (In German).

Özdamar, E. S. (2007). The Bridge of the Golden Horn. London: Serpent's Tail.

Schonfield, E. (2015). 1968 and Transnational History in Emine Sevgi Özdamar’s Die Brücke vom Goldenen Horn. German Life and Letters, 68(1), 66-87. doi: 10.1111/glal.12069 


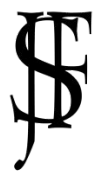

Журнал Фронтирных Исследований. 2021. No 2 | ISSN: 2500-0225

Пограничные исследования в современной европейской литературе | Doi: https://doi.org/10.46539/jfs.v6i2.291

Seyhan, A. (2001). Writing Outside the Nation. Writing Outside the Nation. Princeton, Oxford: Princeton University Press.

Sievers, W. (2008). Writing Politics: The Emergence of Immigrant Writing in West Germany and Austria. Fournal of Ethnic and Migration Studies, 34(8), 1217-1235. doi: 10.1080/13691830802364817

Sievers, W., \& Vlasta, S. (2018). From the Exclusion of Individual Authors to the Transnationalisation of the Literary Field: Immigrant and Ethnic-Minority Writing in Germany. In W. Sievers \& S. Vlasta (Eds.), Immigrant and Ethnic-Minority Writers since 1945. Fourteen National Contexts in Europe and Beyond (pp. 219-258). Leiden, Boston: Brill Rodopi.

Struve, K. (2017). Homi K. Bhabha. In D. Göttsche, A. Dunker, \& G. Dürbeck (Eds.), Handbuch Postkolonialismus und Literatur [Handbook Postcolonialism and Literature] (pp. 16-21). Stuttgart: Springer. (In German). doi: 10.1007/978-3-476-05386-2_3

Tekeli, Ş. (1995). Introduction: Women in Turkey in the 1980s. In Ş. Tekeli (Ed.), Women in Modern Turkish Society. A Reader (pp. 1-22). London: Zed Books.

Thomassen, B. (2018). Thinking with Liminality: To the Boundaries of an Anthropological Concept. In A. Horvart, B. Thomassen, \& H. Wydra (Eds.), Breaking Boundaries. Varieties of Liminality (pp. 39-58). New York, Oxford: Berghahn Books. doi: 10.2307/ j.ctt9qcxbg.6

Wägenbaur, T. (1995). Kulturelle Identität oder Hybridität? Aysel Özakins Die Blaue Maske und das Projekt interkultureller Dynamik [Cultural Identity or Hybridity? Aysel Özakin's The Blue Mask and the Project of Intercultural Dynamics]. Zeitschrift Für Literaturwissenschaft Und Linguistik [fournal for Literary Studies and Linguistics], 25, 22-47. doi: 10.1007/BF03377216

Weber, A. (2009). Im Spiegel der Anderen: Doppelbödige Spurensuche in Aysel Özakins Roman 'Die blaue Maske' [In the Mirror of Others: Double-blooded Search for Traces in Aysel Özakin's Novel ’The Blue Mask]. In Im Spiegel der Migration. Transkulturelles Erzählen und Sprachpolitik bei Emine Sevgi Özdamar [In the Mirror of Migration. Transcultural Narrative and Language Politics in Emine Sevgi Özdamar's Work]. Bielefeld: transcript. (In German).

Weber, B. M. (2010). Work, Sex, and Socialism: Reading Beyond Cultural Hybridity in Eimine Sevgi Özdamar's Die Brücke vom Goldenen Horn. German Life and Letters, 63(1), 37-53. doi: 10.1111/j.1468-0483.2009.01481.x

White, H. (1974). The Historical Text as Literary Artifact. Clio III, 3, 277-303.

Wierschke, A. (1996). Schreiben als Selbstbehauptung: Kulturkonflikte und Identität in den Werken von Aysel Özakin, Alev Tekinay und Emine Sevgi Özdamar [Writing as SelfAssertion: Cultural Conflicts and Identity in the Works of Aysel Özakin, Alev Tekinay and Emine Sevgi Özdamar]. Frankfurt: Verlag für Interkulturelle Kommunikation. (In German).

Yeşilada, K. (1997). Die geschundene Suleika. Das Eigenbild der Türkin in der deutschsprachigen Literatur türkischer Autorinnen [The battered Suleika. The SelfImage of the Turkish Woman in the German-Language Literature of Turkish Women Authors]. In M. Howard (Ed.), Interkulturelle Konfigurationen. Zur 
deutschsprachigen Erzählliteratur von Autoren nichtdeutscher Herkunft [Intercultural Configurations. On German-language narrative literature by authors of non-German origin] (pp. 95-114). München: iudicium verlag. (In German).

Yeşilada, K. (2009). Nette Türkinnen von nebenan'-Die neue deutsch-türkische Harmlosigkeit als literarischer Trend [Nice Turkish Girls Next Door'-The New GermanTurkish Harmlessness as a Literary Trend]. In H. Schmitz (Ed.), Von der nationalen zur internationalen Literatur. Transkulturelle deutschsprachige Literatur und Kultur im Zeitalter globaler Migration [From National to International Literature. Transcultural German-Language Literature and Culture in the Age of Global Migration] (pp. 117142). Amsterdam, New York. (In German).

Yildiz, Y. (2012). Beyond the Mother Tongue: The Postmonolingual Condition. New York: Fordham University Press.

\section{Список литеатуры}

Adelson, L. A. (1997). The Price of Feminism: Of Women and Turks. In P. Herminhouse \& M. Mueller (Eds.), Gener and Germanness. Cultural Productions of Nation (pp. 305319). Providence, Oxford: Berghahn Books.

Adelson, L. A. (2000). Touching Tales of Turks, Germans, and Jews: Cultural Alterity, Historical Narrative, and Literary Riddles for the 1990s. New German Critique, 80, 93-124. doi: $10.2307 / 488635$

Adelson, L. A. (2003). Against Between: A Manifesto. New Perspectives on Turkey, 28-29, 1936. doi: 10.1017/S0 896634600006099

Adelson, L. A. (2005). The Turkish Turn in Contemporary German Literature. Towards a New Critical Grammar of Migration. New York: Palgrave Macmillan.

Anderson, B. (2006). Imagined Communities. Reflections on the Origin and Spread of Nationalism (Revised Ed). London, New York: Verso.

Baumgartner-Karabak, A., \& Landsberger, G. (1978). Die verkauften Bräute. Türkische Frauen zwischen Kreuzberg und Anatolien [The Sold Brides. Turkish Women between Kreuzberg and Anatolia]. Reinbeck: Rowohlt. (In German).

Beck, U. (2002). The Cosmopolitan Society and Its Enemies. Theory, Culture \& Society, 19(1), 17-44. doi: 10.1177/026327640201900101

Berktay, F. (1995). Has Anything Changed in the Outlook of the Turkish Left on Women? In S.. Tekeli (Ed.), Women in Modern Turkish Society. A Reader (pp. 250-262). London: Zed Books.

Bhabha, H. K. (1994). The Location of Culture. London, New York: Routledge Classics.

Boa, E. (2006). Özdamar's Autobiographical Fictions: Trans-National Identity and Literary Form. German Life and Letters, 59(4), 526-539. doi: 10.1111/j.1468-0483.2006.00366.x

Brennan, T. (1990). The national longing for form. In H. K. Bhabha (Ed.), Nation and Narration (pp. 44-70). London, New York: Routledge. 
Bronfen, E. (2000). Vorwort [Foreword]. In E. Bronfen, M. Kessler, P. M. Lützeler, W. Graf Vitzthum, \& J. Wertheimer (Eds.), Die Verortung der Kultur [The location of the culture] (p. IX-XIV). Tübingen: Stauffenburg. (In German).

Brunner, M. E. (1999). Der Fremde erlaubt dir, du selbst zu sein, indem er aus dir einen Fremden macht': Ein Porträt der Autorin Aysel Özakin [The Stranger Allows You to Be Yourself by Making You a Stranger': A Portrait of Author Aysel Özakin]. Arcadia, 34(2), 189-204. (In German).

Brunner, M. E. (2003). Literarische Mehrsprachigkeit und Transkulturalität. Der Dialog zwischen den Kulturen und das Echo von Mimikry und sprachlicher Hybridität im Werk deutsch-türkischer Autorinnen [Literary Multilingualism and Transculturality. The Dialogue between Cultures and the Echo of Mimicry and Linguistic Hybridity in the Work of German-Turkish Women Authors]. Linguistica Antverpiensia, New SeriesThemes in Translation Studies, 2, 115-128. (In German).

Cheesman, T. (2007). Novels of Turkish German Settlement. Cosmopolite Fictions. Rochester, New York: Boydell \& Brewer, Camden House.

Chin, R. (2010). Turkish Women, West German Feminists, and the Gendered Discourse on Muslim Cultural Difference. Public Culture, 22(3), 557-581. doi: 10.1215/08 9923632010-009

Cohen, R. (1986). History and Genre. Neohelicon, 13(2), 87-105.

Dayığlu-Yücel, Y. (2016). Auswahlbibliografie [Selection bibliography]. In Y. Dayığlu-Yücel \& O. Gutjahr (Eds.), Text+Kritik. Emine Sevgi Özdamar (pp. 89-95). München: Richard Boorberg Verlag. (In German).

Dayığlu-Yücel, Y., \& Özdamar, E. S. (2016). 'Das mutigste Mädchen, das diese steile Straße hochläuft'. Gespräch mit Emine Sevgi Özdamar über ihre Begegnungen mit Schriftstellern (August 2015) ['The bravest girl walking up this steep road'. Interview with Emine Sevgi Özdamar about her encounters with writers (August 2015)]. In Y. Dayığlu-Yücel \& O. Gutjahr (Eds.), Text+Kritik. Emine Sevgi Özdamar (pp. 80-88). München: Richard Boorberg Verlag. (In German).

Derrida, J., \& Ronell, A. (1980). The Law of Genre. Critical Inquiry, 7(1), 55-81. doi: $10.1086 / 448088$

Durgun, S. (2015). Left-Wing Politics in Turkey: Its Development and Problems. Arab Studies Quarterly, 37(1), 9-32. doi: 10.13169/arabstudquar.37.1.0009

Ege, M. (2016). Stadt und Sprache als Transiträume bei Emine Sevgi Özdamar. Interkulturelle Einblicke in narrative Topografien [City and Language as Transit Spaces in Emine Sevgi Özdamar. Intercultural Insights into Narrative Topographies]. In Y. Dayığlu-Yücel \& O. Gutjahr (Eds.), Text+Kritik. Emine Sevgi Özdamar (pp. 37-47). München: Richard Boorberg Verlag. (In German).

Ergin, M. (2013). Emine Sevgi Özdamar's Translingual Poetics in Mutterzunge. Seminar: A Fournal of Germanic Studies, 49(1), 20-37. doi: 10.3138/sem.49.1.20

Esselborn, K. (2009). Neue Zugänge zur inter/transkulturellen deutschsprachigen Literatur [New approaches to inter/transcultural German-language literature]. In H. Schmitz (Ed.), Von der nationalen zur internationalen Literatur. Transkulturelle deutschsprachige Literatur und Kultur im Zeitalter globaler Migration [From National 
to International Literature. Transcultural German-Language Literature and Culture in the Age of Global Migration] (pp. 43-58). Amsterdam, New York: Rodopi. (In German).

Fachinger, P. (2001). Rewriting Germany from the Margins. 'Other' German Literature of the 1980s and 1990s. Montreal \& Kingston: McGill-Queen's University Press.

Felski, R. (1989). The Novel of Self-Discovery: Integration and Quest. In Beyond Feminist Aesthetics. Feminist Literature and Social Change (pp. 122-153). London: Hutchinson Radius.

Graham, S. (Ed.). (2019). A History of the Bildungsroman. Cambridge: Cambridge University Press.

Grjasnowa, O. (2019). Privilegien [Privileges]. In F. Aydemir \& H. Yaghoobifarah (Eds.), Eure Heimat ist unser Albtraum [Your homeland is our nightmare] (pp. 130-139). Berlin: Ullstein fünf. (In German).

Gutjahr, O. (2007). Einführung in den Bildungsroman [Introduction to the Bildungsroman]. Darmstadt: Wissenschaftliche Buchgesellschaft.

Gutjahr, O. (2008). Emine Sevgi Özdamars Die Brücke vom Goldenen Horn. Ein interkultureller Bildungsroman [Emine Sevgi Özdamar's The Bridge of the Golden Horn. An Intercultural Bildungsroman]. In R. Riedner \& S. Steinmann (Eds.), Alexandrinische Gespräche [Alexandrian Talks] (pp. 125-140). München: München Iudicium. (In German).

Gutjahr, O. (2016). Inszenierungen eines Rollen-Ich. Emine Sevgi Özdamars theatrales Erzählverfahren [Stagings of a Role-It. Emine Sevgi Özdamar's theatrical narrative process]. In Y. Dayığlu-Yücel \& O. Gutjahr (Eds.), Text+Kritik. Emine Sevgi Özdamar (pp. 8-18). München: Richard Boorberg Verlag. (In German).

Haines, B. (2008). The Eastern Turn in Contemporary German, Swiss and Austrian Literature. Debatte: fournal of Contemporary Central and Eastern Europe, 16(2), 135-149. doi: 10.1080/09651560802316899

Hanson, H., \& O'Rawe, C. (2010). Introduction: 'Cherchez la femme'. In H. Hanson \& C. O’Rawe (Eds.), The Femme Fatale: Images, Histories, Contexts (pp. 1-8). Houndsmills: Palgrave Macmillan.

Hartmann, T. (2021). Deutsch als Literaturheimat. Warum Literatur multilingualer Autorinnen und Autoren einfach deutsche Literatur ist [German as a Literary Homeland. Why Literature by Multilingual Authors is Simply German Literature]. In D. Syrovy (Ed.), Discourses on Nations and Identities (pp. 355-369). Berlin, Boston: De Gruyter. (In German).

Henckmann, G. (1997). Wo Maske und unterdrücktes Ich eins werden’ Zum Motiv der Doppelgängerin in Aysel Özakins Die blaue Maske [Where Mask and Repressed Ego Become One' On the Motif of the Doppelganger in Aysel Özakin's The Blue Mask]. In M. Howard (Ed.), Interkulturelle Konfigurationen. Zur deutschsprachigen Erzählliteratur von Autoren nichtdeutscher Herkunft [Intercultural Configurations. On Germanlanguage narrative literature by authors of non-German origin] (pp. 47-61). München: iudicium verlag. (In German). 
Hermes, S. (2017). Mimikry [Mimicry]. In D. Göttsche, A. Dunker, \& G. Dürbeck (Eds.), Handbuch Postkolonialismus und Literatur [Handbook Postcolonialism and Literature] (pp. 185-187). Stuttgart: Springer. (In German).

Hofmann, M. (2006). Der verfremdete Blick des weiblichen Schelms: Emine Sevgi Özdamar als Erzählerin des Überschreitens [The alienated gaze of the female prankster: Emine Sevgi Özdamar as a narrator of transgression]. In Interkulturelle Literaturwissenschaft. Eine Einführung [Intercultural Literary Studies. An introduction]. Paderborn: Wilhelm Fink. (In German).

Hofmann, M. (2013). Deutsch-türkische Literaturwissenschaft [German-Turkish literary studies]. Würzburg: Könighaus \& Neumann. (In German).

Horrocks, D., \& Kolinsky, E. (1996). Living and Writing in Germany. Emine Sevgi Özdamar in Conversation with David Horrocks and Eva Kolinsky. In D. Horrocks \& E. Kolinsky (Eds.), Turkish Culture in German Society Today (pp. 45-54). Providence, Oxford: Berghahn Books.

Horvart, A., Thomassen, B., \& Wydra, H. (2018). Introduction. Liminality and the Search for Boundaries. In A. Horvart, B. Thomassen, \& H. Wydra (Eds.), Breaking Boundaries. Varieties of Liminality (pp. 1-8). New York, Oxford: Berghahn Books.

Hutcheon, L. (1989). Historiographic Metafiction. Parody and the Intertextuality of History. In P. O’Donnell \& R. C. Davis (Eds.), Intertextuality and contemporary American fiction. Baltimore: Johns Hopkins University Press.

Hutcheon, L. (2002). The Politics of Postmodernism. Routledge.

Johnson, S. (2001). Transnational Ästhetik des türkischen Alltags: Emine Sevgi Özdamar's Das Leben ist eine Karawanserei [Transnational Aesthetics of Turkish Everyday Life: Emine Sevgi Özdamar's Life is a Caravanserai]. The German Quarterly, 74(1), 37-57. doi: 10.2307/3 072 814. (In German)

Kontje, T. (2019). The German Tradition of the Bildungsroman. In S. Graham (Ed.), A History of the Bildungsroman (pp. 10-32). Cambridge: Cambridge University Press. doi: $10.1017 / 9781316479926$

Krause, F. (2000). Shadow Motifs in Emine Sevgi Özdamar's Die Brücke vom Goldenen Horn: A Corrective to the Limitations of Current Debates on Inter-Cultural Issues. fournal of Contemporary Central and Eastern Europe, 8(1), 71-86. doi: 10.1080/713659892

Mälksoo, M. (2018). The Challenge of Liminality for International Relations Theory. In A. Horvart, B. Thomassen, \& H. Wydra (Eds.), Breaking Boundaries. Varieties of Liminality (pp. 226-243). New York, Oxford: Berghahn Books. doi: 10.1017/ S0 260210511000829

Mani, V. B. (2003). The Good Woman of Istanbul: Emine Sevgi Özdamar's Die Brücke vom Goldenen Horn. In P. M. Lützeler \& S. K. Schindler (Eds.), Gegenwartsliteratur. Ein germanistisches Jahrbuch. Schwerpunkt Multikultur [Contemporary Literature. A German Studies Yearbook. Focus on multiculture] (pp. 29-57). Stauffenburg Verlag.

Meske, S. (1983). Situationsanalyse türkischer Frauen in der BRD [Situation Analysis of Turkish Women in the FRG]. Berlin: EXpress Edition. (In German). 
Moretti, F. (1987). Ways of the World. The Bildungsroman in European Culture (A. Sbragia, Ed.). London: Verso.

Nein, nein, nein [Der Spiegel]. (1967, June 4). Retrieved from https://www.spiegel.de/ politik/nein-nein-nein-a-92b28340-0002-0001-0000-000 046251 957?context=issue

Osthues, J. (2017). Rewriting. In D. Göttsche, A. Dunker, \& G. Dürbeck (Eds.), Handbuch Postkolonialismus und Literatur [Handbook Postcolonialism and Literature] (pp. 216219). Stuttgart: Springer. (In German).

Özakin, A. (1989). Die blaue Maske [The blue mask]. Frankfurt am Main: Luchterhand Literaturverlag. (In German).

Özdamar, E. S. (2007). The Bridge of the Golden Horn. London: Serpent's Tail.

Schonfield, E. (2015). 1968 and Transnational History in Emine Sevgi Özdamar's Die Brücke vom Goldenen Horn. German Life and Letters, 68(1), 66-87. doi: 10.1111/glal.12069

Seyhan, A. (2001). Writing Outside the Nation. Writing Outside the Nation. Princeton, Oxford: Princeton University Press.

Sievers, W. (2008). Writing Politics: The Emergence of Immigrant Writing in West Germany and Austria. Journal of Ethnic and Migration Studies, 34(8), 1217-1235. doi: 10.1080/13691830802364817

Sievers, W., \& Vlasta, S. (2018). From the Exclusion of Individual Authors to the Transnationalisation of the Literary Field: Immigrant and Ethnic-Minority Writing in Germany. In W. Sievers \& S. Vlasta (Eds.), Immigrant and Ethnic-Minority Writers since 1945. Fourteen National Contexts in Europe and Beyond (pp. 219-258). Leiden, Boston: Brill Rodopi.

Struve, K. (2017). Homi K. Bhabha. In D. Göttsche, A. Dunker, \& G. Dürbeck (Eds.), Handbuch Postkolonialismus und Literatur [Handbook Postcolonialism and Literature] (pp. 16-21). Stuttgart: Springer. (In German). doi: 10.1007/978-3-476-05 386-2_3

Tekeli, Ş. (1995). Introduction: Women in Turkey in the 1980s. In Ş. Tekeli (Ed.), Women in Modern Turkish Society. A Reader (pp. 1-22). London: Zed Books.

Thomassen, B. (2018). Thinking with Liminality: To the Boundaries of an Anthropological Concept. In A. Horvart, B. Thomassen, \& H. Wydra (Eds.), Breaking Boundaries. Varieties of Liminality (pp. 39-58). New York, Oxford: Berghahn Books. doi: 10.2307/ j.ctt9qcxbg.6

Wägenbaur, T. (1995). Kulturelle Identität oder Hybridität? Aysel Özakins Die Blaue Maske und das Projekt interkultureller Dynamik [Cultural Identity or Hybridity? Aysel Özakin's The Blue Mask and the Project of Intercultural Dynamics]. Zeitschrift Für Literaturwissenschaft Und Linguistik [fournal for Literary Studies and Linguistics], 25, 22-47. doi: 10.1007/BF03377 216

Weber, A. (2009). Im Spiegel der Anderen: Doppelbödige Spurensuche in Aysel Özakins Roman 'Die blaue Maske' [In the Mirror of Others: Double-blooded Search for Traces in Aysel Özakin's Novel 'The Blue Mask]. In Im Spiegel der Migration. Transkulturelles Erzählen und Sprachpolitik bei Emine Sevgi Özdamar [In the Mirror of Migration. Transcultural Narrative and Language Politics in Emine Sevgi Özdamar's Work]. Bielefeld: transcript. (In German). 
Weber, B. M. (2010). Work, Sex, and Socialism: Reading Beyond Cultural Hybridity in Eimine Sevgi Özdamar's Die Brücke vom Goldenen Horn. German Life and Letters, 63(1), 37-53. doi: 10.1111/j.1468-0483.2009.01481.x

White, H. (1974). The Historical Text as Literary Artifact. Clio III, 3, 277-303.

Wierschke, A. (1996). Schreiben als Selbstbehauptung: Kulturkonflikte und Identität in den Werken von Aysel Özakin, Alev Tekinay und Emine Sevgi Özdamar [Writing as SelfAssertion: Cultural Conflicts and Identity in the Works of Aysel Özakin, Alev Tekinay and Emine Sevgi Özdamar]. Frankfurt: Verlag für Interkulturelle Kommunikation. (In German).

Yeşilada, K. (1997). Die geschundene Suleika. Das Eigenbild der Türkin in der deutschsprachigen Literatur türkischer Autorinnen [The battered Suleika. The SelfImage of the Turkish Woman in the German-Language Literature of Turkish Women Authors]. In M. Howard (Ed.), Interkulturelle Konfigurationen. Zur deutschsprachigen Erzählliteratur von Autoren nichtdeutscher Herkunft [Intercultural Configurations. On German-language narrative literature by authors of non-German origin] (pp. 95-114). München: iudicium verlag. (In German).

Yeşilada, K. (2009). Nette Türkinnen von nebenan'-Die neue deutsch-türkische Harmlosigkeit als literarischer Trend [Nice Turkish Girls Next Door'-The New GermanTurkish Harmlessness as a Literary Trend]. In H. Schmitz (Ed.), Von der nationalen zur internationalen Literatur. Transkulturelle deutschsprachige Literatur und Kultur im Zeitalter globaler Migration [From National to International Literature. Transcultural German-Language Literature and Culture in the Age of Global Migration] (pp. 117142). Amsterdam, New York. (In German).

Yildiz, Y. (2012). Beyond the Mother Tongue: The Postmonolingual Condition. New York: Fordham University Press. 